\title{
Trends in body condition in polar bears (Ursus maritimus) from the Southern Hudson Bay subpopulation in relation to changes in sea ice
}

\begin{tabular}{|r|l|}
\hline Journal: & Arctic Science \\
\hline Manuscript ID & AS-2015-0027.R1 \\
\hline Manuscript Type: & Article \\
\hline Complete List of Authors: & $\begin{array}{l}\text { Obbard, Martyn; Ontario Ministry of Natural Resources and Forestry, } \\
\text { Wildlife Research and Monitoring Section } \\
\text { Cattet, Marc; University of Saskatchewan, Canadian Wildlife Health } \\
\text { Cooperative, Western College of Veterinary Medicine } \\
\text { Howe, Eric; Ontario Ministry of Natural Resources and Forestry, Wildlife } \\
\text { Research and Monitoring Section } \\
\text { Middel, Kevin; Ontario Ministry of Natural Resources and Forestry, Wildlife } \\
\text { Research and Monitoring Section } \\
\text { Newton, Erica; Ontario Ministry of Natural Resources and Forestry, Wildlife } \\
\text { Research and Monitoring Section } \\
\text { Kolenosky, George; Ontario Ministry of Natural Resources } \\
\text { Abraham, Kenneth; Ontario Ministry of Natural Resources and Forestry, } \\
\text { Wildlife Research and Monitoring Section } \\
\text { Greenwood, Craig; Ontario Ministry of Natural Resources }\end{array}$ \\
\hline Keyword: & \begin{tabular}{l} 
body condition, climate change, Hudson Bay, polar bear, sea ice \\
\hline
\end{tabular} \\
\hline \hline
\end{tabular}


Trends in body condition in polar bears (Ursus maritimus) from the Southern Hudson Bay subpopulation in relation to changes in sea ice

M.E. Obbard, M.R.L. Cattet, E.J. Howe, K.R. Middel, E.J. Newton, G.B. Kolenosky, K.F. Abraham and C.J Greenwood

M.E. Obbard: Wildlife Research and Monitoring Section, Ontario Ministry of Natural Resources and Forestry, DNA Building, Trent University, 2140 East Bank Drive, Peterborough, ON, Canada K9J 7B8 martyn.obbard@ontario.ca

M.R.L. Cattet: Canadian Wildlife Health Cooperative, Western College of Veterinary Medicine, University of Saskatchewan, 52 Campus Drive, Saskatoon, SK, Canada S7N 5B4 $\underline{\text { mcattet@cwhc-rcsf.ca }}$

E.J. Howe: Wildlife Research and Monitoring Section, Ontario Ministry of Natural Resources and Forestry, DNA Building, Trent University, 2140 East Bank Drive, Peterborough, ON, Canada K9J 7B8 eric.howe@ontario.ca

K.R. Middel: Wildlife Research and Monitoring Section, Ontario Ministry of Natural Resources and Forestry, DNA Building, Trent University, 2140 East Bank Drive, Peterborough, ON, Canada K9J 7B8 kevin.middel@ontario.ca

E.J. Newton: Wildlife Research and Monitoring Section, Ontario Ministry of Natural Resources and Forestry, DNA Building, Trent University, 2140 East Bank Drive, Peterborough, ON, Canada K9J 7B8 erica.newton@ ontario.ca

G.B. Kolenosky: 3790 Cavin Rd., Duncan, BC, Canada V9L 6T2 kolenos_dg3@ @tc.net 
K.F. Abraham: Wildlife Research and Monitoring Section, Ontario Ministry of Natural Resources and Forestry, DNA Building, Trent University, 2140 East Bank Drive, Peterborough, ON, Canada K9J 7B8 ken.abraham@ontario.ca

C.J. Greenwood: 414 Lakewood Dr., Perth, ON, Canada K7H 3C5 louise.craig@ ripnet.com Corresponding author: M.E. Obbard, Wildlife Research and Monitoring Section, Ontario Ministry of Natural Resources and Forestry, DNA Building, Trent University, 2140 East Bank Drive, Peterborough, ON, Canada K9J 7B8. Tel.: (705) 755-1549 FAX: (705) 755-1559 E-mail: martyn.obbard@ontario.ca 
Trends in body condition in polar bears (Ursus maritimus) from the Southern Hudson Bay subpopulation in relation to changes in sea ice

M.E. Obbard, M.R.L. Cattet, E.J. Howe, K.R. Middel, E.J. Newton, G.B. Kolenosky, K.F. Abraham, and C.J. Greenwood

\begin{abstract}
Sea ice is declining over much of the Arctic. In Hudson Bay the ice melts completely each summer, and advances in break-up have resulted in longer ice-free seasons. Consequently, earlier break-up is implicated in declines in body condition, survival, and abundance of polar bears (Ursus maritimus Phipps, 1774) in the Western Hudson Bay (WH) subpopulation. We hypothesised that similar patterns would be evident in the neighbouring Southern Hudson Bay (SH) subpopulation. We examined trends 1980-2012 in break-up and freeze-up dates within the entire SH management unit and within smaller coastal break-up and freeze-up zones. We examined trends in body condition for 900 bears captured during 1984-1986, 2000-2005, and 2007-2009 and hypothesised that body condition would be correlated with duration of sea ice. The ice-free season in SH increased by about 30 days 1980-2012. Body condition declined in all age and sex classes, but the decline was less for cubs than for other social classes. If trends towards a longer ice-free season continue in the future, further declines in body condition and survival rates are likely, and ultimately declines in abundance will occur in the SH subpopulation.
\end{abstract}

Key words: body condition, climate change, Hudson Bay, polar bear, sea ice 


\section{Introduction}

Polar bears (Ursus maritimus Phipps, 1774) rely on sea ice as a platform for important life processes including mating, dispersal, and hunting their primary prey, ringed seals (Pusa hispida Schreber, 1775) and bearded seals (Erignathus barbatus Erxleben, 1777) (Stirling and Archibald 1977). However, the duration of sea ice has declined across much of polar bear range (Stirling and Parkinson 2006), especially in seasonal sea ice regions (Amstrup et al. 2008) such as Hudson Bay (Gagnon and Gough 2005; Scott and Marshall 2010). For example, the open water season in Hudson Bay has increased by about 3 weeks since 1996 (Hochheim and Barber 2014).

The Southern Hudson Bay (SH) subpopulation of polar bears occupies southern and eastern Hudson Bay and James Bay, south of $60^{\circ} \mathrm{N}$ and east of $88.5^{\circ} \mathrm{W}$ (Fig. 1), the southernmost continuously-occupied area of the world-wide range of polar bears (Obbard et al. 2010). Here, climate warming has already caused dramatic changes to the sea ice regime (Gagnon and Gough 2005), and changes to sea ice extent and duration are occurring more rapidly than elsewhere in the Arctic (Hochheim and Barber 2014). Consequently, it is predicted that polar bears may be extirpated from Hudson Bay due to loss of sea ice habitat by the end of the century (Amstrup et al. 2008).

Hudson Bay undergoes a complete cryogenic cycle each year (Etkin 1991); it is entirely covered in ice by late December in most years but the ice melts in summer, so there is a 4-5 month ice-free period in summer and fall. During the ice-free period, all bears are forced ashore where they remain until ice forms again in late fall or early winter. While on land, polar bears generally survive on stored reserves acquired from hunting seals on the ice, though there has long been evidence that at least some bears exploit terrestrial food sources (Russell 1975; 
Derocher et al. 1993; Rockwell and Gormezano 2009; Gormezano and Rockwell 2013). Declines in sea ice affect polar bear populations by reducing the time available to forage; the net result is expected to have both individual- and population-level effects, with individual-level effects being observable earlier than population-level effects (Stirling et al. 1999). In Hudson Bay, polar bears in the Western Hudson Bay $(\mathrm{WH})$ subpopulation have already been affected by changes in sea ice with declines in body condition (Stirling et al. 1999) preceding a $22 \%$ decline in abundance 1987-2004 (Regehr et al. 2007). More recent analysis suggests that from 20012010 there was a period of population stability in WH associated with temporary stability in sea ice conditions that affect survival rates of adult females (Lunn et al. 2016). Nevertheless, further changes in abundance are predicted as the ice-free season becomes longer. For example, Molnár et al. $(2010,2014)$ estimated that $2-3 \%$ of adult males in WH would die before the end of a 120 day summer fasting period but $9-21 \%$ would die if climate warming increases the fasting period to 180 days.

To assess the effects of climate change on the SH subpopulation we examined trends in sea ice duration (1980-2012) and in body condition (1984-2009). We hypothesised that body condition of polar bears in SH would decline as a function of sea ice duration.

\section{Materials and methods}

\section{Animal capture}

In July-October 1984-1986 and September-October 2000-2005 and 2007-2009 we captured polar bears of all age and sex classes along the Ontario coastline from Hook Point $\left(54^{\circ} 50^{\prime} \mathrm{N}, 82^{\circ} 15^{\prime} \mathrm{W}\right)$ on north-western James Bay to the Ontario-Manitoba border $\left(56^{\circ} 50^{\prime} \mathrm{N}\right.$, $89^{\circ} 00^{\prime} \mathrm{W}$ ) and up to $30 \mathrm{~km}$ inland (Fig. 2). We chemically immobilized bears from a helicopter by remote drug delivery using either a combination of ketamine hydrochloride and xylazine 
hydrochloride (KX; 1984-1986), zolazepam-tiletamine (ZT; 2000-2005), a combination of xylazine and zolazepam-tiletamine (XZT; 2007-09) or a combination of medetomidine and zolazepam-tiletamine (MZT; 2009). KX was administered as Ketaset@ (Parke, Davis and Co., Inc., Brockville, Ontario, Canada) at a dosage of $7 \mathrm{mg} / \mathrm{kg}$ estimated body mass and Rompun® (Bayvet Division, Miles Laboratories Ltd., Mississauga, Ontario, Canada) at $7 \mathrm{mg} / \mathrm{kg}$ estimated body mass (Lee et al. 1981). ZT was administered as Telazol® (Fort Dodge Laboratories, Inc., Fort Dodge, Iowa, USA) at $8 \mathrm{mg} / \mathrm{kg}$ estimated body mass (Stirling et al. 1989). XZT was administered as xylazine (Cervizine 300®, Wildlife Pharmaceuticals ,Inc., Fort Collins, Colorado, USA) at $2 \mathrm{mg} / \mathrm{kg}$ and Telazol® (Fort Dodge Laboratories, Inc., Fort Dodge, Iowa, USA) at $3 \mathrm{mg} / \mathrm{kg}$ estimated body mass (Cattet et al. 2003). MZT was administered as medetomidine (Bow River Pharmaceuticals, Bow River, Alberta, Canada) at $0.06 \mathrm{mg} / \mathrm{kg}$ and Telazol ${ }^{\circledR}$ at $2 \mathrm{mg} / \mathrm{kg}$ (Cattet et al. 1997). At the conclusion of handling, we administered yohimbine hydrochloride (1984-1986; Sigma Chemical Co., St. Louis, Missouri, USA) at 0.1 $\mathrm{mg} / \mathrm{kg}$ to reverse the effects of xylazine (Ramsay et al. 1985), or atipamezole (2007-2009; Antisedan®, Pfizer Bio-Pharmaceuticals and Animal Health, Mississauga, Ontario, Canada) at $0.20 \mathrm{mg} / \mathrm{kg}$ to reverse xylazine or $0.30 \mathrm{mg} / \mathrm{kg}$ to reverse medetomidine (Cattet et al. 1997, 2003). Bears $<1$ y of age were immobilized using a pole syringe. In order to avoid the influence of gut fill on body mass, and to ensure bears were not susceptible to aspiration of stomach contents, we did not attempt to handle bears if there was evidence that they might have recently fed (found near a carcass, or with fresh blood on rostrum or forelegs and chest).

Once bears were immobilized, we placed them in ventral (sternal) recumbency with the back legs extended behind and the front legs forward. We recorded pulse and respiratory rates, rectal temperature and, from 2007-2009, haemoglobin oxygen saturation ( Nellcor NPB-40 pulse 
oximeter, Nellcor, Pleasanton, California, USA) at onset of handling and every 15 min thereafter. We protected the corneas of bears by applying $0.5 \%$ hydroxypropyl methyl cellulose eye drops (IsoptoTears ${ }^{\circledR}$, Alcon Canada Inc., Mississauga, Ontario, Canada) and protected the retinas by shielding the eyes with a cotton hood. We recorded standard morphometric measurements (straight-line body length, axillary girth, skull length, zygomatic width, body mass). We measured body length to the nearest $\mathrm{cm}$ as the dorsal straight-line distance from the tip of the nose to the end of the last tail vertebra, using a metal measuring tape extended above the bear in sternal recumbency. We recorded body mass to the nearest $500 \mathrm{~g}$ by suspending the bear from a spring-loaded weigh scale (1984-1986) or an electronic load cell (2000-2009; Norac Ltd., Saskatoon, Saskatchewan, Canada) mounted below a tripod. During weighing, bears were secured in a semi-supportive sling and lifted by chain hoist until clear of the ground. We subtracted the known weight of the supportive sling from the total weight to yield the final scale weight of the bear. We applied individually numbered ear tags and lip tattoos to each animal and removed a vestigial premolar from bears $>1$ y for aging based on counts of cementum growth layers (Calvert and Ramsay 1998).

All capture and handling procedures were approved annually by the Animal Care Committee of the Ontario Ministry of Natural Resources. Handling procedures followed the general guidelines of the Canadian Council for Animal Care (CCAC 2003) and the American Society of Mammalogists (Sikes and Gannon 2011).

\section{Dates of freeze-up, break-up and duration of ice cover}

To describe ice cover on Hudson Bay and James Bay we used ice concentration data at 25-km resolution available as satellite passive microwave data (SMMR/SSMI) obtained from the

National Snow and Ice Data Center, Boulder, Colorado, USA (http://nsidc.org/). We downloaded 
daily ice concentration data in bin format and processed the data to AI grid format using $\mathrm{R}$ version 2.15 (R Core Team 2012) and ArcGIS 9.3.1 (ESRI, Redlands, CA, USA). We clipped the ice data to coincide with the boundaries of the SH subpopulation. We generated daily overall mean ice concentrations in Hudson Bay and James Bay for each year. The duration of ice cover each year is the period between freeze-up in late fall and break-up in early summer. Freeze-up and break-up have generally been defined, following navigation standards, as the period when average sea ice concentration reaches 50\% (Etkin 1991). However, because this metric had low explanatory power in an earlier analysis that examined body condition in SH bears for the period 2003-2005 (Obbard et al. 2006), and because bears in WH were shown to both remain on the ice and return to the ice at lower ice concentrations (Cherry et al. 2013), we also explored whether break-up and freeze-up at lower thresholds of 40\%, 30\%, 20\%, 10\% and 5\% ice concentration were related to body condition levels. We defined freeze-up and break-up dates in each year as the first and last ordinal date, respectively, when the average ice concentration in Hudson Bay and James Bay reached the 6 thresholds and remained either above or below that level.

We tested for temporal trends, 1980-2012, in ordinal dates of freeze-up, break-up and duration of ice cover at the 6 ice concentrations thresholds within the entire SH management unit using Pearson's correlation. A counter-clockwise current flow in Hudson Bay, combined with prevailing north-westerly winds, results in the last remaining ice in summer being concentrated north of the Ontario coast (Wang et al. 1994; Saucier et al. 2004). Because bears remain on this residual ice as it contracts towards the Ontario coast and return to the ice in fall before the entire management unit is ice-covered (Middel 2014), we also tested for trends in ordinal dates of freeze-up and break-up for the 6 ice concentration thresholds in smaller polygons along the Ontario coast of Hudson Bay and James Bay where ice accumulates during break-up in summer 
and where it forms first in late fall (Fig. 3). These smaller break-up and freeze-up coastal zones were defined in part by movement patterns of radio-collared bears (Obbard and Middel 2012; Middel 2013). For the coastal break-up zone we used the July 30 polygon shown in Markham (1988) as being representative of the extent of residual ice off the Ontario coast in early summer in most years. To delimit the extent of the coastal freeze-up zone we measured the distance from shore to the outer ice edge on the day that GPS-collared bears returned to the ice (2007-2010). Average ice extent on the date when bears $(n=30)$ returned to the ice was $47.05 \mathrm{~km}$; therefore, we created a buffer of $50 \mathrm{~km}$ along the northern Ontario shoreline to create our coastal freeze-up zone. We report 1-tailed $P$-values because we expected declines in ice coverage based on previous studies (Gagnon and Gough 2005; Hochheim et al. 2010; Hochheim and Barber 2014).

\section{Trends in polar bear body condition over time}

To estimate a body condition index (BCI) required three steps. First, we tested several models (e.g., linear, logarithmic, inverse, power, quadratic, etc.) using the Curve Estimation command in IBM SPSS Statistics Version 23 (IBM Corporation 2015) to determine which model best described the relationship between body mass and body length in female and male polar bears in our study population. Next, using the best-fitting, sex-specific models, we calculated predicted body mass values and then the residuals as the observed minus predicted body mass values. Finally, following Cattet et al. (2002), we standardized the residuals using a Ztransformation, and used the standardized residuals as our BCI values. Cattet et al. (2002) validated the standardized residual as an index of body condition in polar bears by confirming its strong association with true body condition, defined as the combined mass of fat and skeletal muscle relative to body size, in 31 hunter-killed polar bears. 
We tested for a linear trend in BCI across years and differences in BCI among polar bear capture periods $(1980 \mathrm{~s}=0,2000 \mathrm{~s}=1)$ and social classes (adult $(\geq 5 \mathrm{yr})$ males, adult females accompanied by young, solitary adult females, subadults (2-4 yr), yearlings, and cubs) by comparing linear mixed effects models (with bear as the only random effect) using $\mathrm{AIC}_{c}$ (Hurvich and Tsai 1989). We evaluated support for a difference between the capture period in the 1980 s and the capture period in the 2000s. Most solitary adult females were deemed pregnant at the time of capture based on body mass, but this category likely also included some nulliparous females aged $>4$ years, senescent females, and reproductive-age females that were not accompanied by young but may not have been pregnant in the year of capture We evaluated the effect of two covariates that represented the length of time bears spent on shore because we expected body condition to decrease between the dates that bears came ashore and date of capture in fall (Derocher and Stirling 1995). These covariates were the ordinal date of capture, $o d c$, and estimated number of days ashore since breakup, dashore (odc-ordinal date of breakup at $5 \%$ ice concentration), transformed to begin at "day 1". Both variables were standardized by subtracting the mean and dividing by two standard deviations (Gelman and Hill 2007). Loss of body mass, and therefore a decrease in BCI, is proportional to body temperature and metabolic expenditure (McCue 2010), and polar bear body temperature declines throughout the summer and fall seasons (Whiteman et al. 2015; Obbard unpublished data). Therefore, to account for the possibility that polar bear body condition could decline in a non-linear fashion throughout the duration of the season, we also included a quadratic term for both odc and dashore; these were standardized after squaring.

We included models with interactions between year or capture period and social class because we expected that changes in BCI over time might differ among social classes. We also 
included models with interactions between social class and $o d c$, or dashore, and their quadratics, because different social classes could have different physiological strategies throughout the season in response to food deprivation. At this stage, we retained all bears for which BCI values were available (1071 observations of 900 individuals, Table S1), including dependent offspring. The condition of the offspring likely depended on that of their mothers, so observations may not have been completely independent, but we included data from dependent offspring here because we were interested in differences in BCI and changes in BCI over time, among all age classes including cubs and yearlings. Models were fitted by maximizing the full rather than the restricted likelihood because we were interested in selecting among models with different fixed effects as opposed to random effects (Bolker et al. 2008). When calculating $\mathrm{AIC}_{c}$ values, we set the number of observations to the number of unique individuals rather than the total number of observations. In total, 50 models were included in the candidate set; odc and dashore and their related quadratics were never included in the same model because the two variables were collinear. Similarly, year and capture period were never included in the same models.

Next, we limited the dataset to independent bears (i.e., excluded dependent offspring) and tested for a linear trend through time in years, differences between capture periods, and effects of variables describing ice cover on BCI of independent bears (738 observations of 608 bears, Table S2). Ice variables for the year that BCI was measured were ordinal dates of break-up that year and freeze-up in the previous year as well as the duration of ice cover from freeze-up the previous year to break-up in the current year at each of 50, 40, 30, 20, 10 and 5\% average ice concentration, both within the entire SH management unit and in our smaller defined break-up and freeze-up zones. For ice in the break-up and freeze-up zones, we further included ice durations with all crossed combinations of ice concentrations (e.g., duration of ice cover from 
freeze-up at 50\% ice concentration in fall until break-up at 50, 40, 30, 20, 10 and 5\% ice concentration the following spring). The large number of covariates describing ice cover would have led to a very large number of fitted models if we included all subsets of potential covariates, so we adopted a quasi-stepwise approach to model selection as follows: in Step 1, we initially fit 14 models to confirm that body condition was a function of social class and ordinal date of capture or number of days on shore since breakup at 5\% and their quadratics and interactions, similar to the analysis with dependent bears described above, but without including year or capture period covariates. In Step 2, we fit a set of 71 models containing the top model(s) from Step 1 (i.e., with $\Delta \mathrm{AIC}_{c}$ values $<2$; Burnham and Anderson 2002); the rest of the models included all variables present in the top model(s) and one covariate describing variation among years (either an ice covariate, a linear trend across years, or a difference between capture periods). For Step 3, we added six more models to the set of 71. These models were similar to the six top-ranked models in Step 2, but we included an interaction with the covariate of variation among years for that particular model (year, capture period, or ice covariate) with social class because large interaction effects are likely to occur when main effects are also large (Gelman and Hill 2007). We report results for the final set of 77 models in Step 3. We fit models by maximizing the full likelihood and set the total number of observations to the number of unique individuals when calculating $\mathrm{AIC}_{c}$ values as above. All analyses were performed in $\mathrm{R}$ version 3.2.2 (R Core Team 2015). Mixed effects models were fitted using functions implemented in the lme4 package (Bates et al. 2014). We report the conditional $R^{2}$ for top

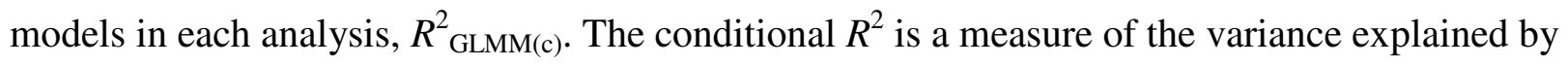
both the fixed and random factors and can be considered an indication of the goodness-of-fit of each model (Nakagawa and Schielzeth 2013). 


\section{Results}

\section{Dates of freeze-up, break-up, and duration of ice cover}

Within the entire SH management unit, ordinal date of freeze-up was positively correlated with year $(P<0.001)$, break-up was negatively correlated with year $(\mathrm{P}<0.05)$, and the duration of ice cover was negatively correlated with year $(\mathrm{P}<0.005)$, at all ice concentrations. For the coastal break-up and freeze-up zones, ordinal date of freeze-up was positively correlated with year $(P<0.05)$ at all ice concentrations, break-up was negatively correlated with year $(P<0.05)$ at all concentrations except at 50\% $(P=0.06)$, and duration of ice cover was negatively correlated with year $(P<0.01)$ at all ice concentrations. For both the entire management unit and the coastal freeze-up and break-up zones, relationships were stronger at lower ice concentrations; therefore, we report trends in freeze-up and break-up for the $5 \%$ ice concentration threshold only. We do not imply that polar bears occupy areas with ice concentration as low as $5 \%$. Rather, the concentration is a mean of all $25 \times 25-\mathrm{km}$ pixels in the defined region ( 90 pixels for our coastal freeze-up zone, 144 pixels for our coastal break-up zone, and 741 pixels for the entire SH management unit). For example, at break-up, even in our smaller coastal zone much of the area will be open water and bears will occupy the residual ice that has much higher ice concentration than 5\%; nevertheless, the mean for the entire polygon is $5 \%$ ice concentration.

At 5\% ice concentration, ordinal dates of freeze-up and break-up changed by approximately 0.5 days per year on average $(\beta=0.53$, SE 0.12 , and $\beta=-0.61$, SE 0.21 , for freeze-up and break-up respectively, in the entire $\mathrm{SH}$ management unit, and $\beta=0.52$, SE 0.20, and $\beta=-0.47$, SE 0.27 , respectively, in the freeze-up and break-up zones near the coast), such that the duration of ice cover decreased by approximately one day per year $(\beta=-1.11, \mathrm{SE} 0.25$ in 
the entire SH management unit, and $\beta=-1.09$, SE 0.40 in the freeze-up and break-up zones). Weaker relationships with break-up dates than freeze-up dates may be attributable to greater variability in break-up dates after 1990 (Figs. 4, 5). Results were similar when we excluded data from 1992, when break-up was particularly late due to the effects of the eruption of Mt. Pinatubo in 1991 (Parks et al. 2006).

\section{Trends in polar bear body condition over time}

The top-ranked model of variation in BCI through time and among social classes fit to the full data set (including dependent offspring) had almost twice as much support as the second ranked model (Table 1). The top model included an effect of the ordinal date of capture, the quadratic term for ordinal date of capture, differences among social classes, the interaction between quadratic ordinal date of capture and social classes, and capture period (Table 1). The second-ranked model was similar to the top model, except that it did not include a quadratic term for $o d c$; instead, it included an interaction between social class and $o d c$. The third model was also similar to the top model, but included a covariate for an interaction between social class and capture period. The top models had similar goodness-of-fit values; however, the fit of the third model was slightly higher than those of the first and second. Though the third- and fourthranked models explained more variance in BCI than the top two models, they had a greater number of parameters and therefore lower AIC weights (Table 1). Other top models were similar to the top four models in that they included interactions between an odc variable and social class, but they included covariates for a change in BCI across years rather than between capture periods, or for an interaction between social classes and the linear relationship across years (Table 1). Neither the dashore term (estimated number of days ashore) nor its quadratic was supported in the top models. 
Body condition decreased significantly for all social classes between the 1980s and 2000s by about one standard deviation of the mean in the three top-ranked models, translating to a loss in body mass of approximately $45 \mathrm{~kg}$ for males and $31 \mathrm{~kg}$ for females (Table 2, Fig. 6). The third-ranked model included an interaction between social class and capture period, suggesting that body condition declined between capture periods at different rates among social classes (Table 2, Fig. 7). In the third model, body condition of cubs declined less rapidly than that of adult males; the rate of change in BCI between capture periods for adult females, subadults, and yearlings was not significantly different from that of adult males (Table 2, Fig. 7).

In terms of time spent ashore, interaction effects precluded interpretation of main effects of social class, $o d c$, and $o d c^{2}$ (Table 2); however, the body condition of adult females and subadults declined more quickly throughout the ice-free season than did body condition of adult males. The decline in BCI for solitary adult females was especially pronounced over the ice-free season (Table 2, Fig. 6). The seasonal trend in BCI for yearlings and cubs was not significantly different from that of adult males.

\section{Factors affecting body condition of independent polar bears}

When we excluded dependent offspring and included ice covariates in the models to explain variation in $\mathrm{BCI}$ over time, the same model of variation in $\mathrm{BCI}$ minimized $\mathrm{AIC}_{c}$ as in the previous analysis (Table 3). Rates of decline in BCI after bears came ashore, between capture periods, and differences among social classes in the rate of change in BCI throughout the season, were similar to when dependent offspring were included (Tables 2, 4). The decline in BCI between capture periods for independent bears translated to approximately $49 \mathrm{~kg}$ for males and $34 \mathrm{~kg}$ for females. Though a decline in BCI between capture periods provided a more parsimonious fit to our BCI data than any of the ice covariates we evaluated, models with an ice 
covariate for ordinal dates of freeze-up at low ice concentrations in the Southern Hudson Bay management unit or the coastal zone were supported over models with other ice covariates. Therefore, the observed decline in body condition was apparently more closely related to later freeze-up than to earlier break-up or shorter ice duration.

\section{Discussion}

We showed that at the lowest ice concentration value of 5\%, break-up advanced and freeze-up was delayed by about 0.5 days/year each on average; therefore, as a result, length of the ice-free period in our study area increased by about 1 day/year between 1980 and 2012 . The net result was that polar bears from the SH subpopulation were forced to spend about 30 days longer on land in 2012 than bears did in 1980. This is similar to earlier estimates of advances in break-up of 3-4 weeks in the western half of Hudson Bay between 1971 and 2003 based on coarser temporal resolution Canadian Ice Service data (Gagnon and Gough 2005), but suggests that the trend has continued. A similar trend to earlier break-up and later freeze-up was documented for northern regions of Hudson Bay in Foxe Basin and Hudson Strait (Sahanatien and Derocher 2012). Variability in the trend in ordinal dates of freeze-up and break-up was greater for our defined coastal zones than for the entire SH management unit which reflects the increased temporal variability in the immediate physical environment that bears in SH now face when either returning to or leaving the sea ice. Increasing variability in the physical environment is one of the general predictions from climate change models (IPCC 2007). It seems that polar bears in SH will be faced with an increasingly unpredictable sea ice regime in the future.

We showed that body condition in all social classes of bears of the SH subpopulation declined significantly between 1984 and 2009—strong evidence for individual-level effects having occurred in this subpopulation. The trend in BCI between capture periods for yearlings, 
subadults, encumbered adult females and solitary adult females were similar to the trend for adult males. However, some models suggested that the decline in body condition was less for cubs than for adult males (Fig. 7). Given that cub body condition declined at a slower rate than that of their mothers, because of the declines in body mass of adult females they may be allocating a proportionally greater amount of energy to their dependent young in recent years such that the energetic cost to themselves is proportionally higher than in the 1980s. If that is the case, this portends further declines in body condition of reproductive-age females and subsequent declines in reproductive success. Declines in body condition between capture periods for solitary females may have been less than that for encumbered females, which also may reflect the proportional increase in energetic costs of reproduction for lactating females in recent years due to their declining body mass (Table 2, Fig. 7). However, the solitary female class had small sample sizes in some years and also likely included nulliparous adult females, older unencumbered adult females that may not have been pregnant, and senescent females, leading to greater variability in the data and subsequent large SE associated with the parameter estimates. This meant that we could not distinguish the trend for solitary females from that for encumbered females.

There were interesting differences among social classes in trends of body condition during time ashore (Fig. 6). Compared to adult males, the greater rate of decline in body condition for subadults presumably represents the energetic costs of somatic growth. The relatively greater declines for encumbered adult females presumably reflect the energetic costs of lactation, though by late September few adult females in this subpopulation are still lactating (Obbard, unpublished data). The trend for solitary adult females may be more an artefact of small samples sizes and subsequent high variability in the data. The trend for cubs and yearlings 
did not differ from that for adult males, and the pattern suggests that, at least for the late summer and early fall period, many cubs and yearlings are still benefitting from nursing.

It has been suggested that exploiting terrestrial food sources may ameliorate declines in body condition in polar bears (e.g., Gormezano and Rockwell 2015), though the importance of terrestrial foraging in offsetting lost opportunities to hunt seals remains controversial (e.g., Rode et al. 2015). Bears in WH have been documented feeding on various terrestrial food sources (Derocher et al. 1993; Rockwell and Gormezano 2009; Gormezano and Rockwell 2013). Similarly, SH bears were reported to exploit terrestrial foods during the ice-free season as far back as the 1970s (Russell 1975), and more recently (Smith and Hill 1996). However, the current extent and opportunities for terrestrial feeding are not well understood for the SH subpopulation. It is uncertain how important terrestrial feeding may be for these bears in the future, but body condition declined since the 1980s while bears have had opportunities to exploit terrestrial food sources.

Declines in individual-level traits can be expected to presage declines in population-level traits, especially in long-lived animals such as bears where females can control reproductive effort through delayed implantation (Wimsatt 1963; Hellgren 1998). In both the WH and Southern Beaufort Sea subpopulations, declines in body condition preceded declines in survival rates and litter production rates (Stirling et al. 1999; Regehr et al. 2007, 2010; Rode et al. 2010, 2012), and these negative trends were correlated with declines in sea ice duration and distribution. For example, Regehr et al. (2007) suggested that survival of juveniles, subadults, and senescent-adult polar bears in WH was correlated with spring sea ice break-up date, which was variable among years and occurred approximately 3 weeks earlier in 2004 than in 1984. The authors argued that this correlation provided evidence for a causal association between earlier 
sea ice break-up (due to climatic warming) and decreased polar bear survival, resulting in a decline in abundance (Regehr et al. 2007).

Based on results of capture-recapture studies conducted in SH from 1984-1986 and 2003-2005, Obbard et al. (2007) showed that survival rates tended to decline during that period, although point estimates were not significantly different because of the overlap in confidence intervals. Recently, results of intensive aerial surveys conducted in 2011 in WH (Stapleton et al. 2014) and SH (Obbard et al. 2015) suggested that reproductive output, as measured by average litter size and proportion of cubs and yearlings in the sample, was greater in $\mathrm{SH}$ than in WH. This suggests that, despite the demonstrated declines in body condition and the suggestion of declines in survival rates, reproductive output in $\mathrm{SH}$ is still better than that of the neighbouring subpopulation. In contrast to the situation in the WH subpopulation, no decline in abundance was detected in the SH subpopulation between the mid-1980s and 2012 (Obbard et al. 2015).

Nevertheless, if these trends in body condition and survival rates continue, declines in abundance seem inevitable. Because no change in abundance has yet been detected in the SH subpopulation it seems unlikely that density-dependent factors are influencing body condition of bears. Rather, it seems more likely that declines in body condition in $\mathrm{SH}$ are related to changes in the physical environment, that is, to decreases in the length of time Hudson Bay is ice-covered and providing a suitable platform for hunting.

Date of freeze-up had a stronger influence on subsequent body condition than date of break-up in our study. Though models with date of freeze-up were supported over models with other ice covariates, we acknowledge that lower variability in freeze-up dates than in ice duration or break-up dates could have influenced the model selection process. Nevertheless, we suggest that a stronger effect of date of freeze-up may be because even though break-up has advanced by 
up to 3-4 weeks in portions of Hudson Bay it still occurs no earlier than late June or early July so does not yet interfere with opportunities to feed on neonate ringed seal pups that are born in March-April in eastern Hudson Bay (Chambellant 2010). Therefore, losing days or weeks of hunting opportunities during June and July deprives polar bears of the opportunity to feed on adult seals, but does not deprive them of the critical spring period (Watts and Hansen 1987) when they are truly hyperphagic. No doubt, the loss of hunting opportunities to kill adult seals has a negative effect on body condition, but it appears that for bears in $\mathrm{SH}$ a forced extension of the fast in late fall has a greater negative effect on subsequent body condition. Because the bears now return to the ice in poorer condition than in previous decades they have a greater energy deficit to recover during a now shorter hunting season. The additive effects of continued declines in the time available to acquire energy stores on long-lived animals such as polar bears will eventually have negative outcomes. An even longer ice-free season will result in further reduced access to prey, lowered fat stores, greater physiological stress and eventually effects on survival and reproductive success (Derocher et al. 2004; Molnár et al. 2010, 2011; Stirling and Derocher 2012).

Molnár et al. $(2010,2011)$ predicted that an ice-free period $\geq 180$ days would cause large declines in survival rates and reproduction for polar bears in $\mathrm{WH}$. Based on these predictions Castro de la Guardia et al. (2013) defined critical years for polar bears in this subpopulation as those with $\geq 180$ ice-free days and projected changes in the ice cycle and in sea ice concentration in spring under 3 IPCC greenhouse gas emissions scenarios (B1, A1B, A2). Under all 3 scenarios, critical years were more common after 2050; from 2051-2100, 8 critical years were predicted to occur under the B1 scenario, 35 under the A1B scenario, and 41 under the A2 scenario (Castro de la Guardia et al. 2013). Therefore, in two emissions scenarios polar bear 
habitat will deteriorate rapidly after 2050 and the polar bears in WH will be increasingly less likely to persist. However, if greenhouse gas emissions can be reduced (B1 scenario), sea ice habitat will deteriorate less rapidly and polar bears should persist through the $21^{\text {st }}$ century (Castro de la Guardia et al. 2013). Future research on polar bears in SH should address forecasting when sea ice changes can be expected to greatly reduce survival and reproduction. Analysing detailed fine-scale temporal and spatial data from polar bears fitted with GPS radiocollars would improve our understanding of the ice conditions when polar bears abandon the ice platform and return to land in spring and when they return to the ice in fall. This information is critical to understanding the marginal sea ice conditions that polar bears will continue to use as a hunting platform.

\section{Acknowledgements}

We thank the many helicopter pilots, fixed wing pilots, and aircraft maintenance engineers who supported our capture efforts over the years. We also thank the many Ontario Ministry of Natural Resources staff members who assisted with field work. Funding for field work in 1984-1986 was provided by the Ontario Ministry of Natural Resources (OMNR). Funding for field work from 2000-2005 was provided by OMNR's Wildlife Research and Development Section, Nunavut Department of Environment, Makivik Corporation, Ontario Parks, Safari Club International (Ontario Chapter), Safari Club International (Detroit Chapter), Les Brasseurs du Nord, La Fondation de la Faune du Québec, La Societé de la faune et des parcs du Québec, and OMNR's Climate Change Program: Projects CC-03/04-010, CC-04/05-002, and CC-05/06-036. Funding for field work from 2007-2009 was provided by OMNR's Wildlife 
Research and Development Section, OMNR's Climate Change Program, and Toronto Zoo's Endangered Species Reserve Fund. Comments from K. Rode, G. Thiemann, and R. Watt helped us to improve an earlier version of the manuscript.

\section{References}

Amstrup, S.C., Marcot, B.G., and Douglas, D.C. 2008. A Bayesian network modeling approach to forecasting the $21^{\text {st }}$ century worldwide status of polar bears. Pages 213-268 In Arctic sea ice decline: Observations, projections, mechanisms, and implications. Edited by E.T. DeWeaver, C.M. Bitz, and L.B. Tremblay. American Geophysical Union Monogr. Ser. No. 180, Washington, D.C. pp. 213-268.

Bates, D., Maechler, M., Bolker, B., and Walker, S. 2014. lme4: Linear mixed-effects models using Eigen and S4. R package version 1.1-7, http://CRAN.R-project.org/package=lme4 accessed 1 September 2015.

Bolker, B.M. 2008. Ecological models and data in R. Princeton University Press, Princeton, New Jersey.

Burnham, K.P., and Anderson, D.R. 2002. Model selection and multimodel inference: A practical information-theoretic approach. Springer, Berlin.

Calvert, W., and Ramsay, M.A. 1998. Evaluation of age determination of polar bears by counts of cementum growth layer groups. Ursus 10: 449-453.

Canadian Council on Animal Care. CCAC guidelines on the care and use of wildlife. 2003. Canadian Council on Animal Care, Ottawa, Ont. 
Castro de la Guardia, L., Derocher, A.E., Myers, P.G., Terwisscha van Scheltinga, A.D., and Lunn, N.J. 2013. Future sea ice conditions in Western Hudson Bay and consequences for polar bears in the 21st century. Glob. Change Biol. 19: 2675-2687.

Cattet, M.R.L., Caulkett, N.A., and Lunn, N.J. 2003. Anesthesia of polar bears using xylazinezolazepam-tiletamine or zolazepam-tiletamine. J. Wildl. Dis. 39: 655-664.

Cattet, M.R.L., Caulkett, N.A., Obbard, M.E., and Stenhouse, G.B. 2002. A body-condition index for ursids. Can. J. Zool. 80: 1156-1161.

Cattet, M.R.L., Caulkett, N.A., Polischuk, S.C., and Ramsay, M.A. 1997. Reversible immobilization of free-ranging polar bears with medetomidine-zolazepam-tiletamine and atipamezole. J. Wildl. Dis. 33: 611-617.

Chambellant, M. 2010. Hudson Bay ringed seal: Ecology in a warming climate. In A Little Less Arctic: Top predators in the world's largest northern inland sea, Hudson Bay. Edited by S.H. Ferguson, L.L. Loseto, and M.L. Mallory. Springer, Netherlands. pp. 137-158.

Cherry, S.G., Derocher, A.E., Thiemann, G.W., and Lunn, N.J. 2013. Migration phenology and seasonal fidelity of an Arctic marine predator in relation to sea ice dynamics. J. Anim. Ecol. 82: 912-921.

Derocher, A.E., Andriashek, D., and Stirling, I. 1993. Terrestrial foraging by polar bears during the ice-free period in western Hudson Bay. Arctic 46: 251-254.

Derocher, A.E., Lunn, A.E., and Stirling, I. 2004. Polar bears in a warming climate. Integr. Comp. Biol. 44: 163-176.

Derocher, A.E., and Stirling, I. 1995. Temporal variation in reproduction and body mass of polar bears in western Hudson Bay. Can. J. Zool. 73: 1657-1665. 
Etkin, D.A. 1991. Break-up in Hudson Bay: Its sensitivity to air temperatures and implications for climate warming. Climatol. Bull. 25: 21-34.

Gagnon, A.S., and Gough, W.A. 2005. Trends in the dates of ice freeze-up and break-up over Hudson Bay, Canada. Arctic 58: 370-382.

Gelman, A., and Hill, J. 2007. Data analysis using regression and multilevel/hierarchical models. Cambridge University Press, New York.

Gormezano, L.J., and Rockwell, R.F. 2013. Dietary composition and spatial patterns of polar bear foraging on land in western Hudson Bay. BMC Ecology 13: 51.

Gormezano, L.J. and Rockwell, R.F. 2015. The energetic value of land-based foods in western Hudson Bay and their potential to alleviate energy deficits of starving adult male polar bears. PLOS ONE 10: e128520.

Hellgren, E.C. 1998. Physiology of hibernation in bears. Ursus 10: 467-477.

Hochheim, K.P., and Barber, D.G. 2014. An update on the ice climatology of the Hudson Bay system. Arct., Antarct. Alp. Res. 46: 66-83.

Hochheim, K., Barber, D.G., and Lukovich, J.V. 2010. Changing sea ice conditions in Hudson Bay, 1980-2005. In A Little Less Arctic: Top predators in the world's largest northern inland sea, Hudson Bay. Edited by S.H. Ferguson, L.L. Loseto, and M.L. Mallory. Springer, Netherlands. pp. 39-52.

Hurvich, C.M., and Tsai, C-L. 1989. Regression and time series model selection in small samples. Biometrika 76: 297-307.

IBM Corporation. 2015. IBM SPSS Statistics Version 23. IBM Corporation, Armonk, NY. IPCC. 2007. Climate Change 2007: The Physical Science Basis. Contribution of Working Group I to the Fourth Assessment Report of the Intergovernmental Panel on Climate 
Change. Edited by S. Solomon, D. Qin, M. Manning, Z. Chen, M. Marquis, K.B. Averyt, M. Tignor and H.L. Miller. Cambridge University Press, Cambridge, U.K. and New York, NY. 996 pp.

Kuznetsova, A., Brockhoff, P.B., and Christensen, R.H.B. 2015. 1merTest: Tests in linear mixed effects models. R package version 2.0-29. http://CRAN.R-project.org/package=lmerTest, accessed 1 September 2015.

Lee, J., Schweinsburg, R., Kernan, F., and Haigh, J. 1981. Immobilization of polar bears (Ursus maritimus, Phipps) with ketamine hydrochloride and xylazine hydrochloride. J. Wildl. Dis. 17: 331-335.

Lunn, N.J., Branigan, M., Carpenter, L., Justus, J., Hedman, D., Larsen, D., Lefort, S., Maraj, R., Obbard, M.E., Peacock, L., and Pokiak, F. 2010. Polar bear management in Canada, 2005-2008. In Polar Bears: Proceedings of the 15th working meeting of the IUCN/SSC Polar Bear Specialist Group, Copenhagen, Denmark, 29 June-3 July 2009. Edited by M.E. Obbard, G.W. Thiemann, E. Peacock, and T.D. DeBruyn. Occasional Paper of the IUCN Species Survival Commission, No. 43. IUCN, Gland, Switzerland and Cambridge, UK. pp. 87-113.

Lunn, N.J., Servanty, S., Regehr, E.V., Converse, S.J., Richardson, E., and Stirling, I. 2016. Demography of an apex predator at the edge of its range-impacts of changing sea ice on polar bears in Hudson Bay. Ecological Applications, in press. doi: 10.1890/15-1256.

McCue, M.D. 2010. Starvation physiology: Reviewing the different strategies animals use to survive a common challenge. Comp Biochem Phys A 156: 1-18. 
Middel, K. R. 2014. Movement parameters and space use for the Southern Hudson Bay polar bear subpopulation in the face of a changing climate. Thesis. Trent University, Peterborough, Ontario, Canada.

Molnár, P.K., Derocher A.E., Klanjscek T., and Lewis M.A. 2011. Predicting climate change impacts on polar bear litter size. Nature Comm 2: 186, 1-8.

Molnár, P.K., Derocher, A.E., Thiemann, G.W., and Lewis, M.A. 2010. Predicting survival, reproduction and abundance of polar bears under climate change. Biol. Conserv. 143: 1612-1622.

Molnár, P.K., Derocher, A.E., Thiemann, G.W., and Lewis, M.A. 2014. Corrigendum to: "Predicting survival, reproduction and abundance of polar bears under climate change" [Biol. Conserv. 143(2010): 1612-1622]. Biol. Conserv. 177: 9-10.

Nakagawa, S., and Schielzeth, H., 2013. A general and simple metho d for obtaining $R^{2}$ from generalized linear mixed-effects models. Methods Ecol Evol 4: 133-142.

Obbard, M.E., Cattet, M.R.L., Moody, T., Walton, L.R., Potter, D., Inglis, J., and Chenier, C. 2006. Temporal trends in the body condition of Southern Hudson Bay polar bears. Climate Change Research Information Note, No. 3. Ontario Ministry of Natural Resources, Sault Ste. Marie, Ont.

Obbard M.E., McDonald, T.L., Howe. E.J., Regehr, E.V., and Richardson, E.S. 2007. Polar bear population status in Southern Hudson Bay, Canada. U.S. Geological Survey, Reston, VA.

Obbard, M.E., and Middel, K.R. 2012. Bounding the Southern Hudson Bay polar bear subpopulation. Ursus 23: 134-144. 
Obbard, M.E., Stapleton, S., Middel, K.R., Thibault, I., Brodeur, V., and Jutras, C. 2015. Estimating the abundance of the Southern Hudson Bay polar bear subpopulation with aerial surveys. Polar Biol. 38: 1713-1725.

Obbard, M.E., Thiemann, G.W., Peacock, E., and DeBruyn, T.D., editors. 2010. Polar Bears: Proceedings of the $15^{\text {th }}$ working meeting of the IUCN/SSC Polar Bear Specialist Group, 29 June--3 July 2009, Copenhagen, Denmark. Occasional Paper of the IUCN Species Survival Commission, No. 43. International Union for Conservation of Nature and Natural Resources (IUCN), Gland, Switzerland and Cambridge, UK.

Parks, E.K., Derocher, A.E., and Lunn, N.J. 2006. Seasonal and annual movement patterns of polar bears on the sea ice of Hudson Bay. Can. J. Zool. 84: 1281-1294.

R Core Team. 2012. R: A language and environment for statistical computing, version 2.15. R Foundation for Statistical Computing, Vienna, Austria. http://www.R-project.org/, accessed 15 March 2013.

R Core Team. 2015. R: A language and environment for statistical computing, version 3.2.2. R Foundation for Statistical Computing, Vienna, Austria. http://www.R-project.org/, accessed 1 September 2015.

Ramsay, M.A., Stirling, I., Knutsen, L.Ø., and Broughton, E. 1985. Use of yohimbine to reverse immobilization of polar bears by ketamine hydrochloride and xylazine hydrochloride. J. Wildl. Dis. 21: 390-394.

Regehr, E.V., Hunter, C.M., Caswell, H., Amstrup, S.C., and Stirling, I. 2010. Survival and breeding of polar bears in the southern Beaufort Sea in relation to sea ice. J. Anim. Ecol. 79: $117-127$. 
Regehr, E.V., Lunn, N.J., Amstrup, S.C., and Stirling, I. 2007. Effects of earlier sea ice breakup on survival and population size of polar bears in western Hudson Bay. J. Wildl. Manage. 71: 2673-2683.

Rockwell, R.F., and Gormezano, L.J. 2009. The early bear gets the goose: climate change, polar bears and lesser snow geese in western Hudson Bay. Polar Biol. 32: 539-547.

Rode, K.D., Amstrup, S.C., and Regehr, E.V. 2010. Reduced body size and cub recruitment in polar bears associated with sea ice decline. Ecol. Appl. 20: 768-782.

Rode, K.D., Peacock, E., Taylor, M., Stirling, I., Born, E.W., Laidre, K.L., and Wiig, Ø. 2012. A tale of two polar bear populations: ice habitat, harvest, and body condition. Popul. Ecol. 54: 3-18.

Rode, K.D., Robbins, C.T., Nelson, L., and Amstrup, S.C. 2015. Can polar bears use terrestrial foods to offset lost ice-based hunting opportunities? Front. Ecol. Environ. 13: 138-145.

Russell, R.H. 1975. Food habits of polar bears of James Bay and southwest Hudson Bay in summer and autumn. Arctic 28: 117-129.

Sahanatien, V., and Derocher, A.E. 2012. Monitoring sea ice habitat fragmentation for polar bear conservation. Anim. Conserv. 15: 397-406.

Saucier, F.J., Senneville, S., Prinsenberg, F.R., Smith, G., Gachon, P., Caya, D., and Laprise, R. 2004. Modelling the sea ice-ocean seasonal cycle in Hudson Bay, Foxe Basin and Hudson Strait, Canada. Clim. Dynam. 23: 303-326.

Scott, J.B.T., and Marshall, G.J. 2010. A step-change in the date of sea-ice break-up in western Hudson Bay. Arctic 63: 155-164.

Sikes, R.S. and Gannon, W.L. 2011. Guidelines of the American Society of Mammalogists for the use of wild mammals in research. J. Mamm. 92: 235-253. 
Smith, A.E., and Hill, M.R.J. 1996. Polar bear, Ursus maritimus, depredation of Canada Goose, Branta canadensis, nests. Can. Field-Nat. 110: 339-340.

Stapleton, S., Atkinson, S., Hedman, D., and Garshelis, D. 2014. Revisiting Western Hudson Bay: Using aerial surveys to update polar bear abundance in a sentinel population. Bio. Conserv. 170: $38-47$.

Stirling, I., and Archibald, W.R. 1977. Aspects of predation of seals by polar bears. J. Fish. Res. Board Can. 34: 1126-1129

Stirling I., and Derocher, A.E. 2012. Effects of climate warming on polar bears: a review of the evidence. Glob. Change Biol. 18: 2694-2706.

Stirling, I., Lunn, N.J., and Iacozza, J. 1999. Long-term trends in the population ecology of polar bears in Western Hudson Bay in relation to climatic change. Arctic 52: 294-306.

Stirling, I., and Parkinson, C.L. 2006. Possible effects of climate warming on selected populations of polar bears (Ursus maritimus) in the Canadian Arctic. Arctic 59: 261-275.

Stirling, I., Spencer, C., and Andriashek, D. 1989. Immobilization of polar bears (Ursus maritimus) with Telazol® in the Canadian Arctic. Arctic 25: 159-168.

Wang, J., Mysak, L.A., and Ingram, R.G. 1994. A numerical simulation of sea ice cover in Hudson Bay. J. Phys. Oceanogr. 24: 2515-2533.

Watts, P., and Hansen, S. 1987. Cyclic starvation as a reproductive strategy in the polar bear. Symp. Zool. Soc. Lond. 57: 305-318.

Whiteman, J.P., Harlow, H.J., Durner, G.M., Anderson-Sprecher, R., Albeke, S.E., Regehr, E. V, Amstrup, S.C., and Ben-David, M. 2015. Summer declines in activity and body temperature offer polar bears limited energy savings. Science 349: 295-298. 
Wimsatt, W.A. 1963. Delayed implantation in the Ursidae, with particular reference to the black bear (Ursus americanus Pallas). In Delayed implantation. Edited by A.C. Enders. Univ. Chicago Press, Chicago. pp. 69-77. 


\section{Figure Captions}

Fig. 1. Recognized boundaries of Canadian polar bear subpopulations. SB-South Beaufort, NBNorth Beaufort, VM-Viscount Melville, NW-Norwegian Bay, LS-Lancaster Sound, MCM'Clintock Channel, GB-Gulf of Boothia, BB-Baffin Bay, DS-Davis Strait, FB-Foxe Basin, WH-Western Hudson Bay, SH-Southern Hudson Bay (Lunn et al. 2010).

Fig. 2 Location of study area in the northern Ontario. Polar bears were captured between the Manitoba/Ontario border and Hook Point on James Bay, and up to $30 \mathrm{~km}$ inland.

Fig. 3. Map of Hudson Bay and James Bay showing orientation of surface currents and the Southern Hudson Bay management unit boundaries with our defined coastal break-up and freeze-up zones.

Fig. 4. Ordinal dates of freeze-up (grey dots) and break-up (hollow circles), and the duration of ice cover (black dots), all to 5\% ice concentration, within the Southern Hudson Bay polar bear management unit,1980-2012. Text labels show Pearson's correlation coefficients for the linear relationships depicted, all of which were significant at $\alpha=0.05$.

Fig. 5. Ordinal dates of freeze-up (grey dots) and break-up (hollow circles), and the duration of ice cover (black dots), all to 5\% ice concentration, for the coastal break-up and freeze-up zones off the northern Ontario coast and coast of James Bay in Ontario, Canada, 1980-2012. Text labels show Pearson's correlation coefficients for the linear relationships depicted, all of which were significant at $\alpha=0.05$. 
Fig. 6. Standardized body condition index values (BCI) and top-model regression lines by social class and capture period for polar bears, including dependent offspring, in the Southern Hudson Bay subpopulation, 1984-1986 and 2000-2009 (excluding 2006).

Fig. 7. Interaction between social class and two capture periods, 1984-1986 and 2000-2009 (excluding 2006), as predicted by the third model describing variation in standardized body condition index values (BCI) for polar bears, including dependent offspring, in the Southern Hudson Bay subpopulation. Ordinal date of capture was held constant at the median date of capture of 19 September. 


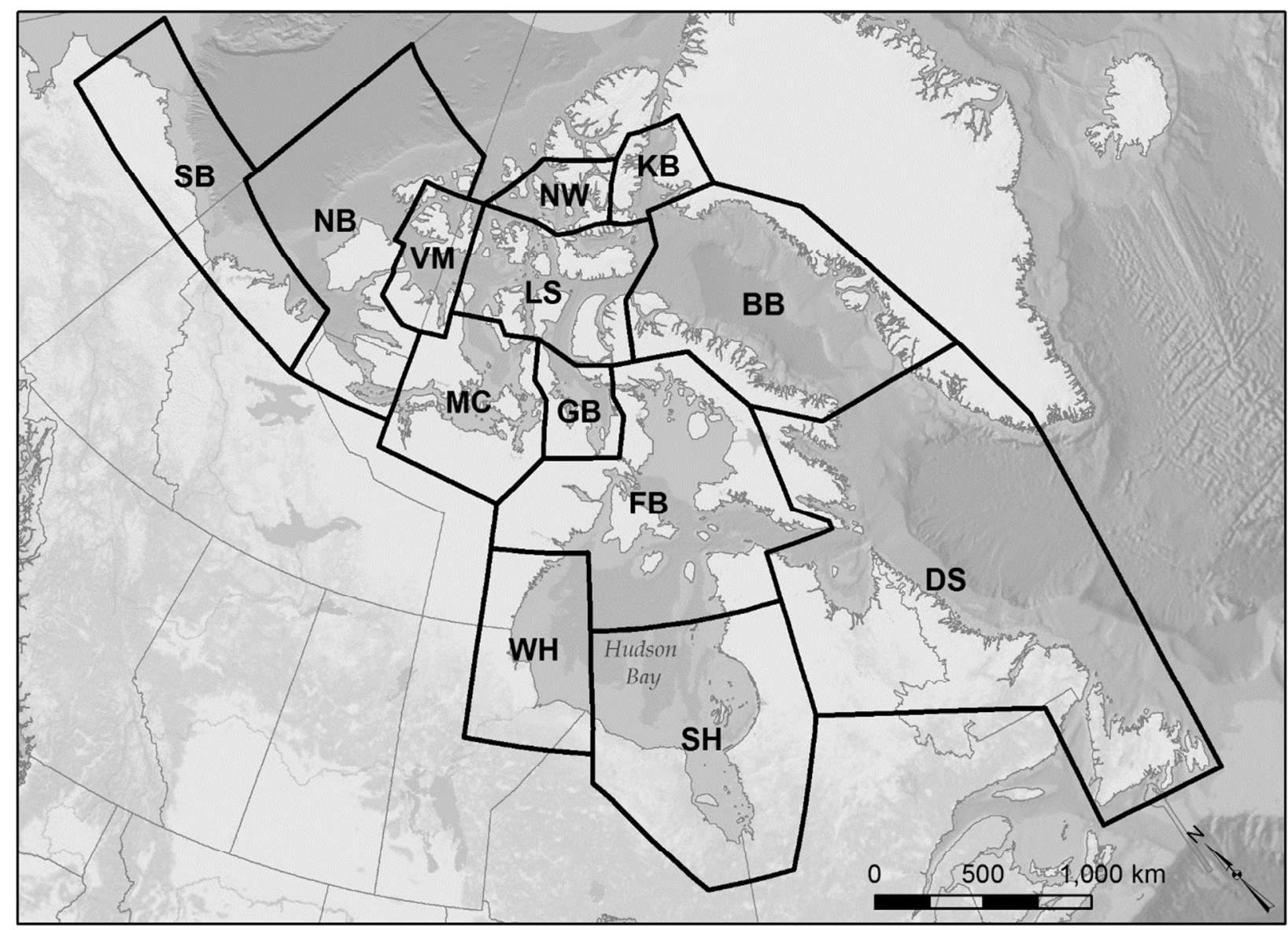

Fig. 1. Recognized boundaries of Canadian polar bear subpopulations. SB-South Beaufort, NBNorth Beaufort, VM-Viscount Melville, NW-Norwegian Bay, LS-Lancaster Sound, MCM'Clintock Channel, GB-Gulf of Boothia, BB-Baffin Bay, DS-Davis Strait, FB-Foxe Basin, WH-Western Hudson Bay, SH-Southern Hudson Bay (Lunn et al. 2010) 


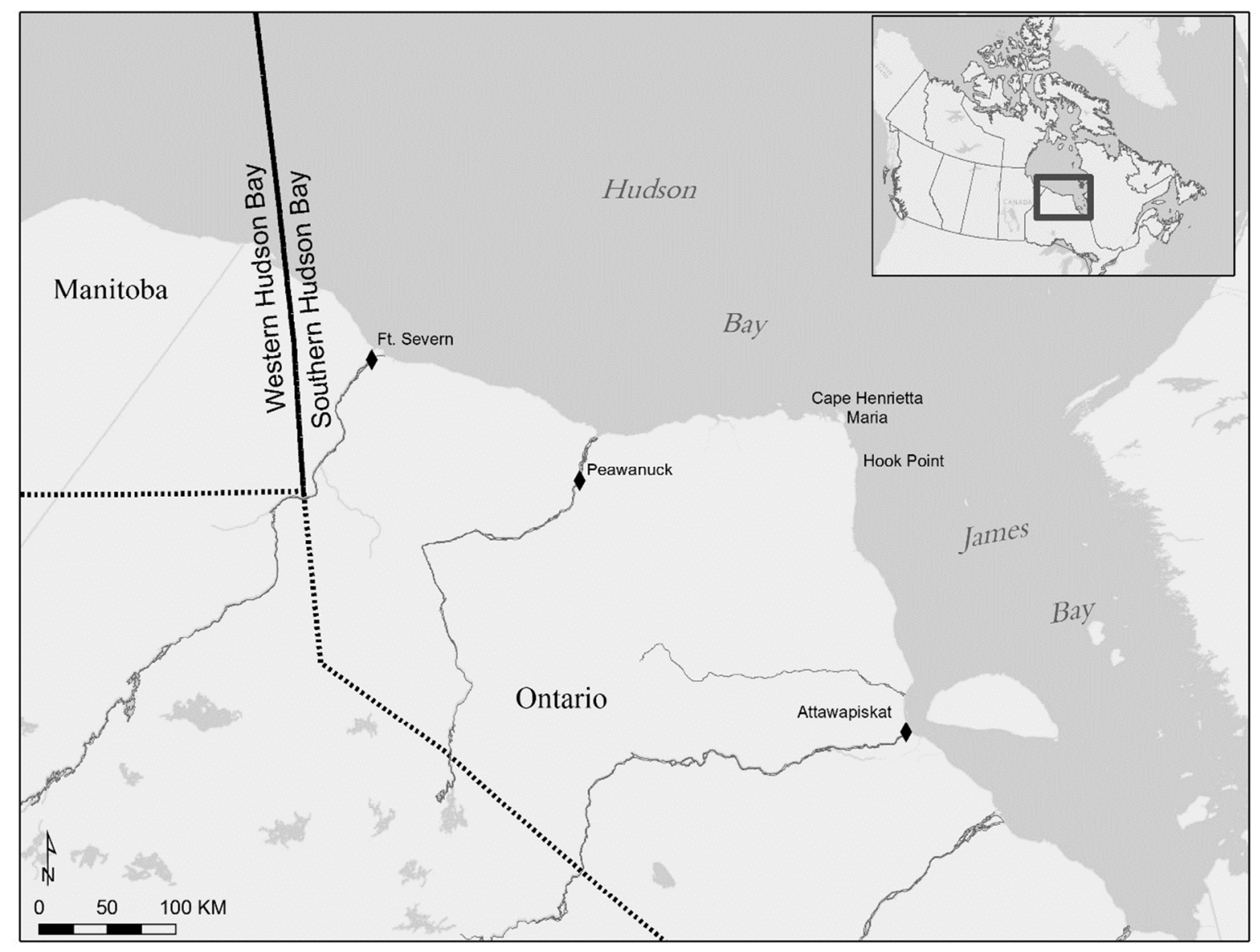

Fig. 2 Location of study area in the northern Ontario. Polar bears were captured between the Manitoba/Ontario border and Hook Point on James Bay, and up to $30 \mathrm{~km}$ inland. 


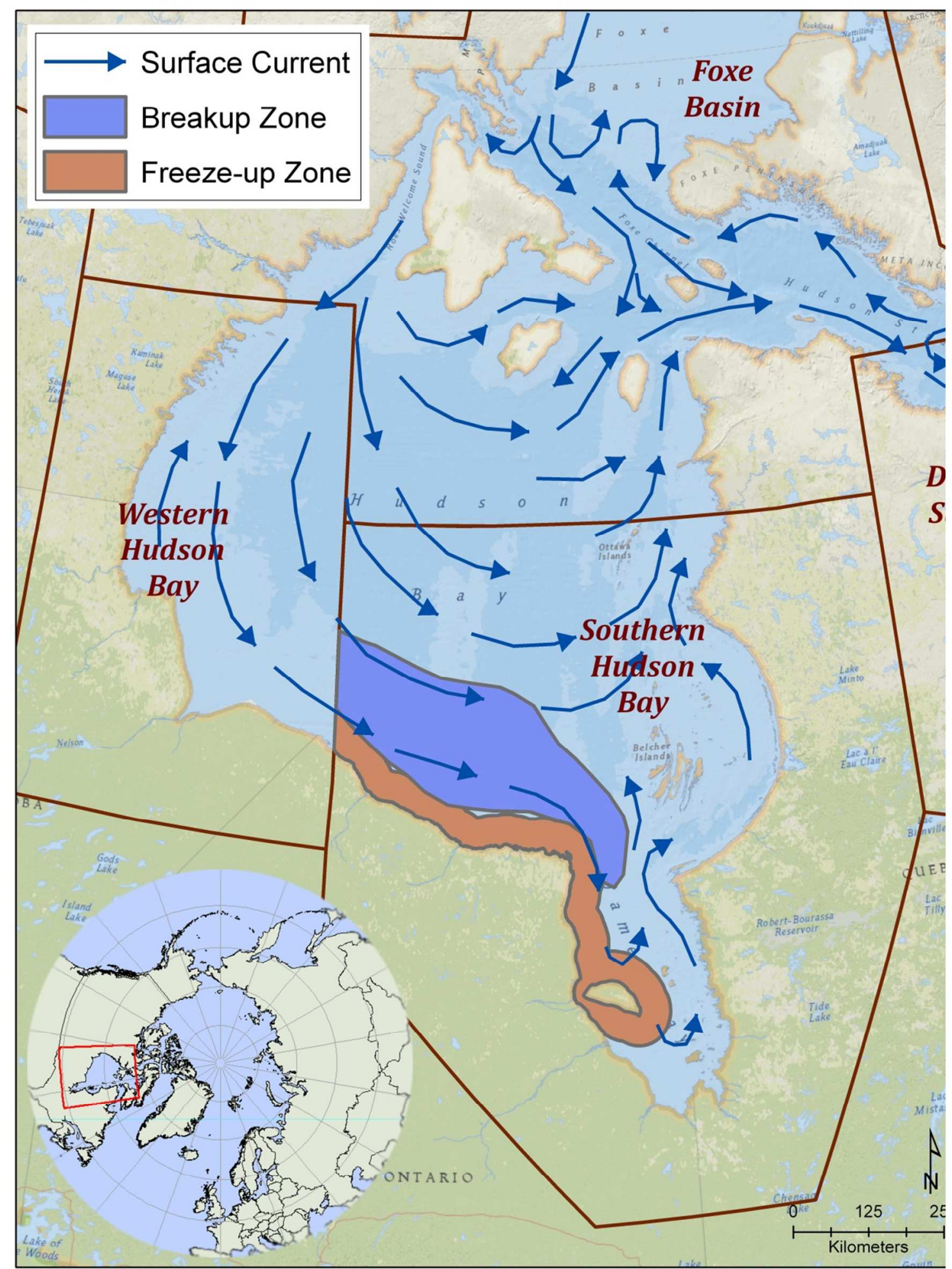

Fig. 3. Map of Hudson Bay and James Bay showing orientation of surface currents and the Southern Hudson Bay management unit boundaries with our defined coastal break-up and freeze-up zones. 


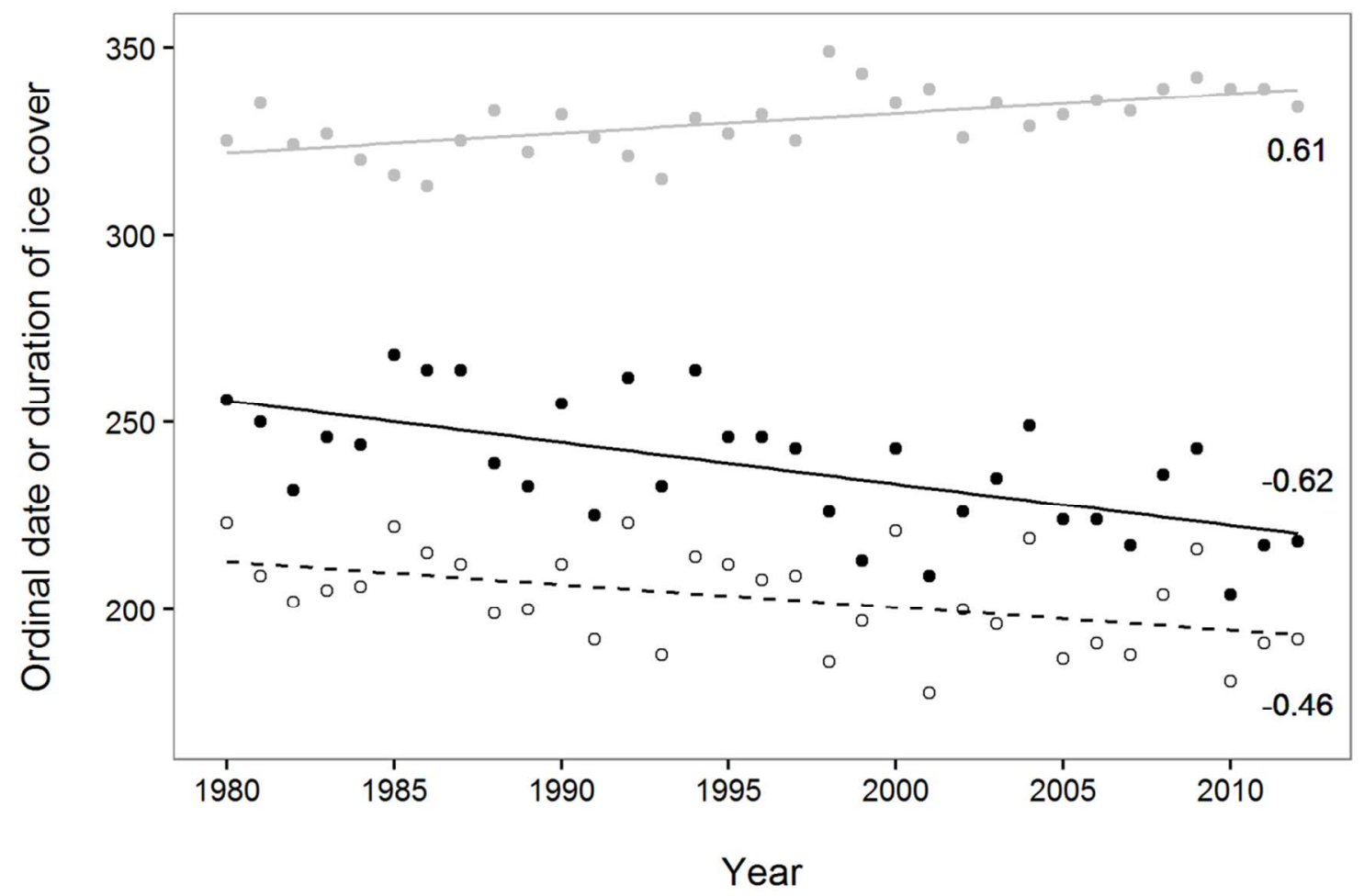

Fig. 4. Ordinal dates of freeze-up (grey dots) and break-up (hollow circles), and the duration of ice cover (black dots), all to 5\% ice concentration, within the Southern Hudson Bay polar bear management unit,1980-2012. Text labels show Pearson's correlation coefficients for the linear relationships depicted, all of which were significant at $\alpha=0.05$. 


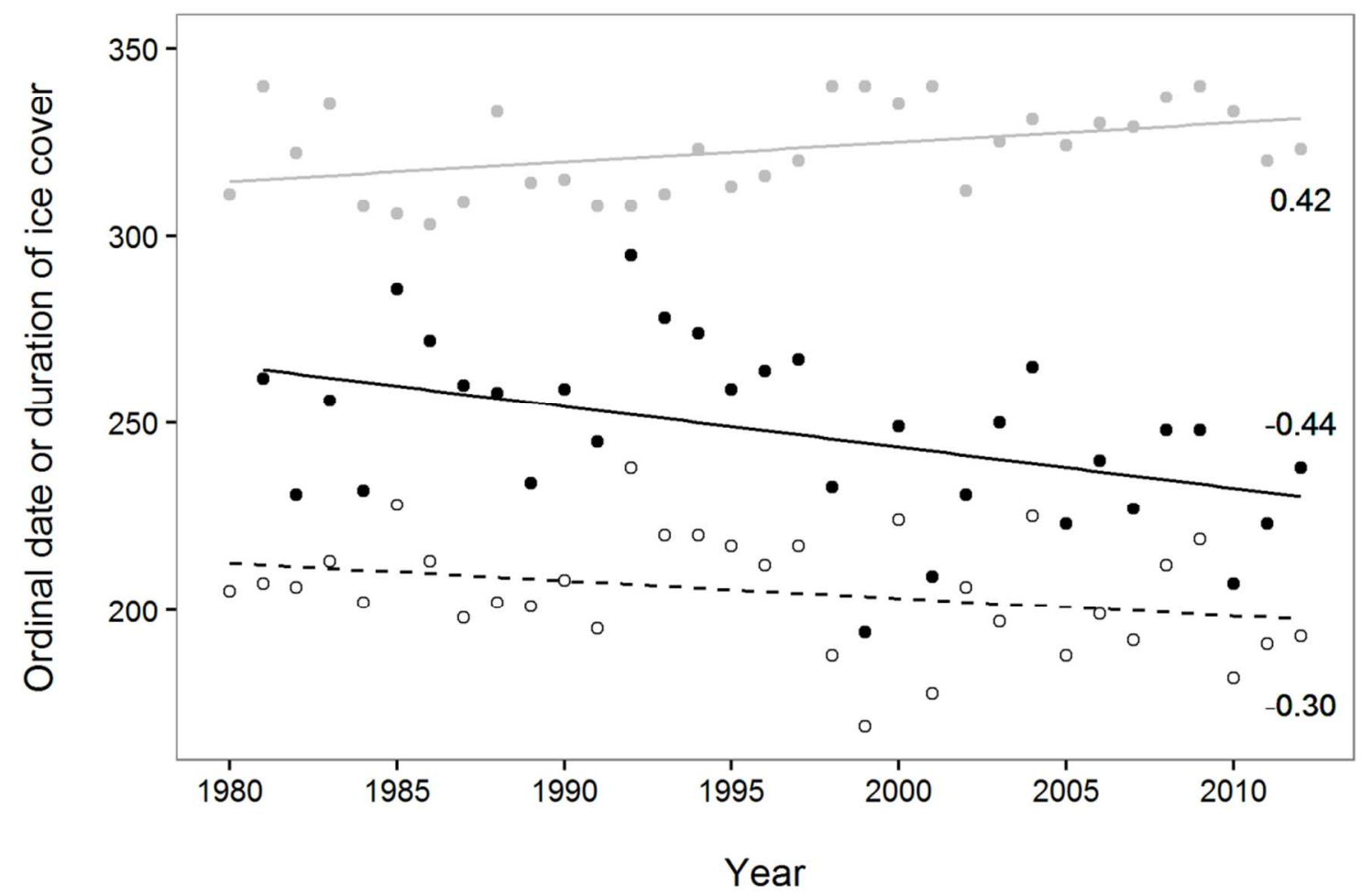

Fig. 5. Ordinal dates of freeze-up (grey dots) and break-up (hollow circles), and the duration of ice cover (black dots), all to 5\% ice concentration, for the coastal break-up and freeze-up zones off the northern Ontario coast and coast of James Bay in Ontario, Canada, 1980-2012. Text labels show Pearson's correlation coefficients for the linear relationships depicted, all of which were significant at $\alpha=0.05$. 

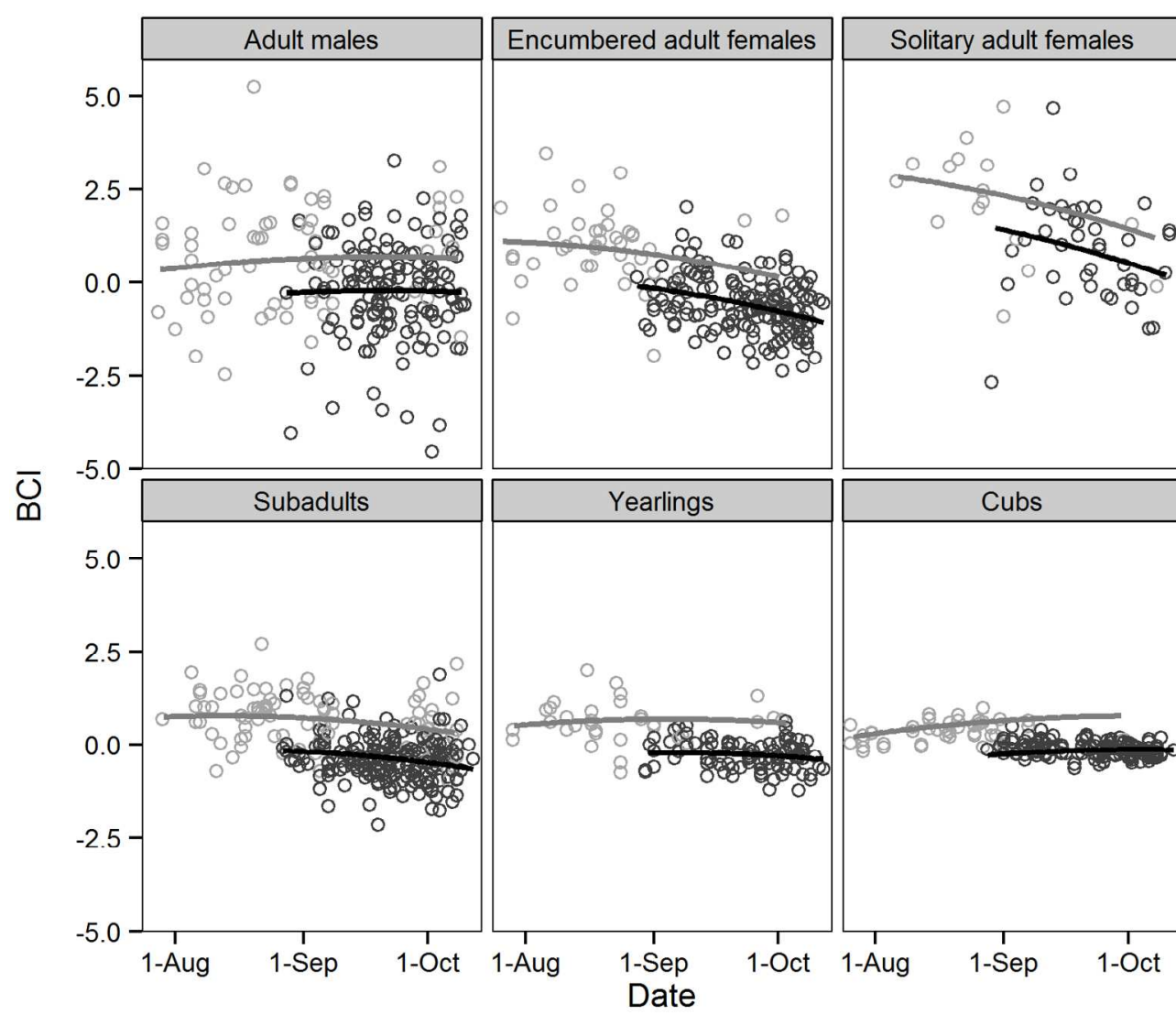

\section{Capture Period}

- 1980s

- 2000s

- 1980s

$-2000 \mathrm{~s}$

Fig. 6. Standardized body condition index values (BCI) and top-model regression lines by social class and capture period for polar bears, including dependent offspring, in the Southern Hudson Bay subpopulation, 1984-1986 and 2000-2009 (excluding 2006). 


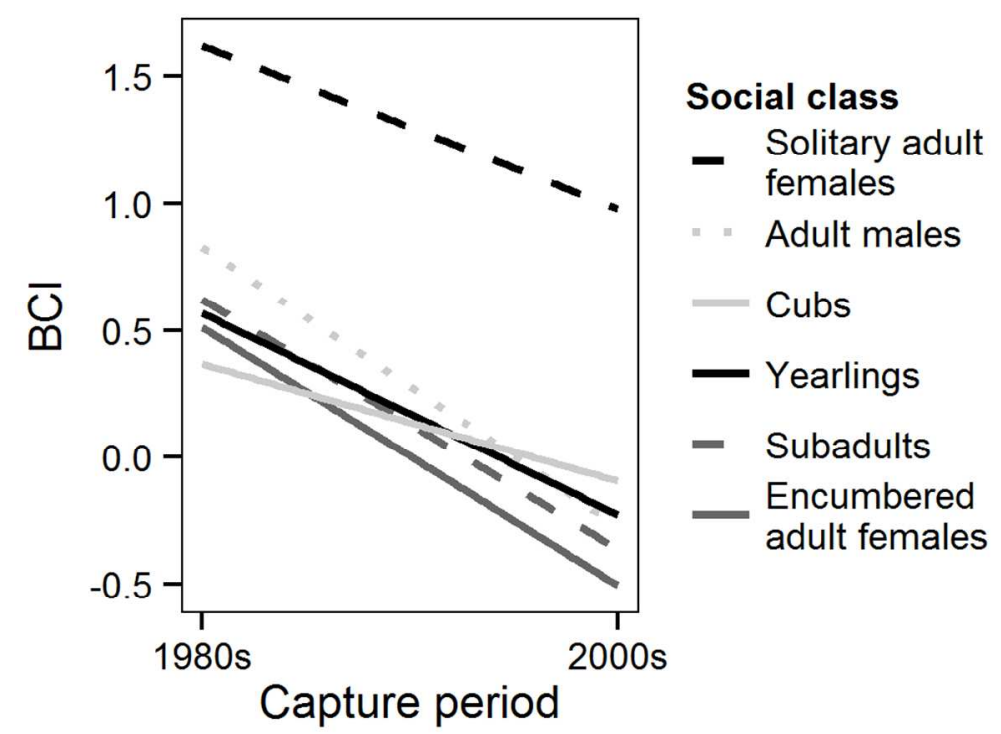

Fig. 7. Interaction between social class and two capture periods, 1984-1986 and 2000-2009 (excluding 2006), as predicted by the third model describing variation in standardized body condition index values (BCI) for polar bears, including dependent offspring, in the Southern Hudson Bay subpopulation. Ordinal date of capture was held constant at the median date of capture of 19 September. 
Table 1. Model selection results for the top ranked of 50 models of variation in body condition index of polar bears and their dependent offspring in the Southern Hudson Bay subpopulation, 1984-1986 (capture period = 0), and $2000-2009$ excluding $2006($ capture period $=1)$. In model names, $o d c=$ ordinal date of capture, dashore $=o d c-$ ordinal date when ice concentration at breakup was at 5\%, soc $=$ social class (adult male, adult female accompanied by young, solitary adult female, subadult, yearling, cub), and a multiplication sign indicates interactions between main effects; "year" was modeled as a linear relationship.

\begin{tabular}{lrrrrr}
\hline Model & Parameters & $\mathrm{AIC}_{c}$ & $\Delta \mathrm{AIC}_{c}$ & $w_{i}$ & $R_{\text {GLMM(c) }}^{2}$ \\
\hline$o d c+o d c^{2} \times s o c+$ capture period & 16 & 2615.59 & 0 & 0.44 & 0.534 \\
$o d c \times s o c+$ capture period & 15 & 2616.82 & 1.23 & 0.24 & 0.534 \\
$o d c+o d c^{2} \times s o c+s o c \times$ capture period & 21 & 2618.06 & 2.47 & 0.13 & 0.536 \\
$o d c \times s o c+s o c \times$ capture period & 20 & 2619.04 & 3.45 & 0.08 & 0.537 \\
$o d c \times s o c+$ year & 15 & 2619.19 & 3.6 & 0.07 & 0.534 \\
$o d c+o d c^{2} \times s o c+$ year & 16 & 2621.17 & 5.58 & 0.03 & 0.533 \\
$o d c \times s o c+s o c \times$ year & 20 & 2623.19 & 7.6 & 0.01 & 0.531 \\
$o d c+o d c^{2} \times s o c+s o c \times$ year & 21 & 2625.14 & 9.55 & 0.00 & 0.531 \\
$o d c+o d c^{2}+s o c \times$ capture period & 16 & 2632.58 & 16.99 & 0.00 & 0.517 \\
$d a s h o r e+d a s h o r e^{2}+s o c \times$ year & 16 & 2632.71 & 17.12 & 0.00 & 0.513 \\
$o d c+s o c \times$ year & 15 & 2633.85 & 18.26 & 0.00 & 0.516 \\
$o d c+o d c^{2}+s o c \times$ year & 16 & 2634.95 & 19.35 & 0.00 & 0.516 \\
$o d c+s o c \times$ capture period & 2635.73 & 20.14 & 0.00 & 0.517 \\
\hline & & & & & \\
\hline
\end{tabular}


Table 2. Parameter estimates for factors affecting body condition of polar bears and their dependent offspring in the Southern Hudson Bay subpopulation, 1984-1986 and 2000-2009 (excluding 2006), with standard errors and approximate $P$-values calculated using Satterthwaite-approximated degrees of freedom (Kuznetsova et al. 2015) for the three top-ranked models. Adult males were the reference class; $o d c=$ ordinal date of capture, $s o c=$ social class, $c p=$ capture period.

\begin{tabular}{|c|c|c|c|c|c|c|c|c|c|}
\hline \multirow[b]{3}{*}{ Effect } & \multicolumn{9}{|c|}{ Model } \\
\hline & \multicolumn{3}{|c|}{$o d c+o d c^{2} \times s o c+c p$} & \multicolumn{3}{|c|}{$o d c \times s o c+c p$} & \multicolumn{3}{|c|}{$o d c+o d c^{2} \times s o c+s o c \times c p$} \\
\hline & $\beta$ & SE & $P$ & $\beta$ & SE & $P$ & $\beta$ & SE & $P$ \\
\hline Intercept & 0.6482 & 0.0814 & $<0.0001 *$ & 0.6117 & 0.0793 & $<0.0001 *$ & 0.7804 & 1.3474 & $<0.0001^{*}$ \\
\hline$o d c$ & 2.3377 & 1.3455 & 0.0826 & 0.0858 & 0.1191 & 0.4714 & 2.1468 & 1.3457 & 0.1114 \\
\hline$o d c^{2}$ & -2.2345 & 1.3401 & 0.0957 & & & & -1.9405 & 0.2131 & 0.1496 \\
\hline Encumbered adult females & -0.1992 & 0.0842 & $0.0183 *$ & -0.2072 & 0.0843 & $0.0142 *$ & -0.2504 & 0.2763 & 0.2402 \\
\hline Solitary adult females & 1.2345 & 0.1222 & $<0.0001 *$ & 1.2457 & 0.1223 & $<0.0001^{*}$ & 0.9062 & 0.1573 & $0.0011^{*}$ \\
\hline Subadults & -0.0870 & 0.0770 & 0.2587 & -0.0793 & 0.0771 & 0.3036 & -0.1676 & 0.2167 & 0.2870 \\
\hline Yearlings & -0.0194 & 0.0941 & 0.8369 & -0.0254 & 0.0942 & 0.7872 & -0.2348 & 0.2111 & 0.2787 \\
\hline Cubs & 0.0473 & 0.0816 & 0.5623 & 0.0414 & 0.0817 & 0.6122 & -0.4396 & 0.1613 & $0.0375^{*}$ \\
\hline$c p$ & -0.9129 & 0.0801 & $<0.0001 *$ & -0.8622 & 0.0757 & $<0.0001^{*}$ & -1.1026 & 0.2172 & $<0.0001 *$ \\
\hline Encumbered adult females $\times$ odc ${ }^{2}$ & -0.7507 & 0.1591 & $<0.0001 *$ & & & & -0.7905 & 0.3243 & $0.0003 *$ \\
\hline Solitary adult females $\times o d c^{2}$ & -1.0793 & 0.2548 & $<0.0001^{*}$ & & & & -1.3507 & 0.1843 & $<0.0001 *$ \\
\hline Subadults $\times o d c^{2}$ & -0.3862 & 0.1543 & $0.0125^{*}$ & & & & -0.4569 & 0.2384 & $0.0133^{*}$ \\
\hline Yearlings $\times o d c^{2}$ & -0.1430 & 0.1786 & 0.4234 & & & & -0.3152 & 0.2165 & 0.1864 \\
\hline $\mathrm{Cubs} \times o d c^{2}$ & 0.1089 & 0.1561 & 0.4855 & & & & -0.2671 & 1.3474 & 0.2176 \\
\hline Encumbered adult females $\times$ odc & & & & -0.7648 & 0.1589 & $<0.0001^{*}$ & & & \\
\hline Solitary adult females $\times$ odc & & & & -1.1345 & 0.2565 & $<0.0001 *$ & & & \\
\hline Subadults $\times$ odc & & & & -0.4125 & 0.1541 & $0.0076^{*}$ & & & \\
\hline Yearlings $\times$ odc & & & & -0.1555 & 0.1786 & 0.3840 & & & \\
\hline Cubs $\times$ odc & & & & 0.1145 & 0.1556 & 0.4621 & & & \\
\hline Encumbered adult females $\times c p$ & & & & & & & 0.0852 & 0.2634 & 0.7463 \\
\hline Solitary adult females $\times c p$ & & & & & & & 0.4589 & 0.3422 & 0.1802 \\
\hline Subadults $\times c p$ & & & & & & & 0.1165 & 0.1987 & 0.5577 \\
\hline Yearlings $\times c p$ & & & & & & & 0.3063 & 0.2760 & 0.2673 \\
\hline Cubs $\times c p$ & & & & & & & 0.6409 & 0.2586 & $0.0134^{*}$ \\
\hline
\end{tabular}


Table 3. Model selection results for the top ranked of 77 models of variation in body condition index of independent polar bears (i.e., excluding dependent offspring) in the Southern Hudson Bay subpopulation, 1984-1986 (capture period =0), and 2000-2009 excluding 2006 (capture period $=1$ ). In model names, $o d c=$ ordinal date of capture, $s o c=$ social class (adult male, adult female accompanied by young, solitary adult female, subadult), and a multiplication sign indicates interactions between main effects; “year" was modeled as a linear relationship.

\begin{tabular}{lccrrr}
\hline Model & Parameters & $\mathrm{AIC}_{c}$ & $\Delta \mathrm{AIC}$ & $w_{i}$ & $R_{\text {GLMM(c) }}^{2}$ \\
\hline$o d c+o d c^{2} \times s o c+$ capture period & 12 & 2034.95 & 0 & 0.84 & 0.596 \\
$o d c+o d c^{2} \times s o c+$ year & 12 & 2039.57 & 4.63 & 0.08 & 0.589 \\
$o d c+o d c^{2} \times$ soc + soc $\times$ capture period & 15 & 2040.05 & 5.10 & 0.07 & 0.594 \\
$o d c+o d c^{2} \times s o c+s o c \times$ year & 15 & 2043.83 & 8.89 & 0.01 & 0.586 \\
$o d c+o d c^{2} \times s o c+$ SHMU freeze-up [5\%] & 12 & 2085.55 & 50.60 & 0.00 & 0.564 \\
$o d c+o d c^{2} \times s o c+s o c \times$ SHMU freeze-up [5\%] & 15 & 2091.18 & 56.24 & 0.00 & 0.566 \\
$o d c+o d c^{2} \times s o c+$ SHMU freeze-up [20\%] & 12 & 2092.83 & 57.88 & 0.00 & 0.575 \\
$o d c+o d c^{2} \times s o c+$ SHMU freeze-up [10\%] & 12 & 2095.15 & 60.21 & 0.00 & 0.570 \\
$o d c+o d c^{2} \times s o c+$ SHMU freeze-up [40\%] & 12 & 2095.76 & 60.81 & 0.00 & 0.574 \\
$o d c+o d c^{2} \times s o c+$ SHMU freeze-up [30\%] & 12 & 2098.41 & 63.47 & 0.00 & 0.576 \\
$o d c+o d c^{2} \times s o c+$ coastal freeze-up [20\%] & 12 & 2098.85 & 63.91 & 0.00 & 0.578 \\
$o d c+o d c^{2} \times s o c+s o c \times$ SHMU freeze-up [20\%] & 15 & 2098.93 & 63.98 & 0.00 & 0.572 \\
$o d c+o d c^{2} \times s o c+$ coastal freeze-up [40\%] & 12 & 2100.73 & 65.79 & 0.00 & 0.580
\end{tabular}


Table 4. Parameter estimates for the top-ranked model for factors affecting body condition of independent polar bears (i.e., excluding dependent offspring) in the Southern Hudson Bay subpopulation, 1984-1986 and 2000-2009 (excluding 2006), with standard errors and approximate $P$-values calculated using Satterthwaite-approximated degrees of freedom (Kuznetsova et al. 2015). Adult males were the reference class; odc $=$ ordinal date of capture, $s o c$ $=$ social class.

\section{Model}

$$
o d c+o d c^{2} \times s o c+\text { capture period }
$$

\begin{tabular}{|c|c|c|c|}
\hline Effect & $\beta$ & $\mathrm{SE}$ & $P$ \\
\hline Intercept & 0.6962 & 0.1037 & $<0.0001 *$ \\
\hline$o d c$ & 1.7606 & 1.9131 & 0.3577 \\
\hline$o d c^{2}$ & -1.6252 & 1.9050 & 0.3939 \\
\hline Encumbered adult females & -0.1979 & 0.1001 & $0.0484 *$ \\
\hline Solitary adult females & 1.2564 & 0.1430 & $<0.0001 *$ \\
\hline Subadults & -0.0698 & 0.0912 & 0.4442 \\
\hline Capture period & -0.9873 & 0.1083 & $<0.0001^{*}$ \\
\hline Encumbered adult females $\times$ od $c^{2}$ & -0.7416 & 0.1829 & $0.0001 *$ \\
\hline Solitary adult females $\times o d c^{2}$ & -1.0942 & 0.2892 & $0.0002 *$ \\
\hline Subadults $\times$ od $c^{2}$ & -0.3805 & 0.1775 & $0.0324 *$ \\
\hline
\end{tabular}

